\title{
The Moderating Effect of Government Policy on Strategic Leadership and Performance of County Governments in North Rift Region, Kenya
}

\author{
Apalia Antony ${ }^{1}$ and Ondiek B. Alala ${ }^{2 *}(\mathrm{PhD})$ \\ Phd Student ${ }^{1}$ and Lecturer ${ }^{2}$, Department of Accounting and Finance, School of Business and Economics, Masinde Muliro University of Science and \\ Technology, P.O. BOX 190-50100 Kakamega, Kenya
}

Received 12 Aug 2018, Accepted 15 Oct 2018, Available online 17 Oct 2018, Vol.6 (Sept/Oct 2018 issue)

\begin{abstract}
The Constitution of Kenya 2010 reversed the centralized non - participatory governance paradigm by institutionalizing a devolved governance system. A total of 47 counties were created in the constitution. Each county was to receive funding from the National government and at the same time generate funds to sustain themselves. Devolution approaches tailored to sub-national, regional and local circumstances were considered better able to address the continuing problems caused by entrenched territorial inequities in growth, income and employment. These counties are streamlined under government polices where evaluation is done and planned early in the policy development cycle and embedded into all policies. The objectives of the study were to determine the moderating effect of government policy on strategic leadership and performance of county governments in North Rift region, Kenya. The study adopted mixed research design that targeted 539 county governments' employees in the North Rift region. A sample size of 230 employees was determined and selected by use of stratified random sampling technique. The main study instrument was self-administered questionnaire and interview guide. Validity was determined by population and content validity. Reliability of instruments was tested by use of Cronbach's alpha. Both descriptive statistics and inferential statistics were adopted. It was noted that government policy has a moderating role because in its presence, it accounts for $53 \%$ of the performance of county government while in its absence, the performance can only be attributed to $49.2 \%$. The study concluded that government policy has a moderating effect with performance in the county government.
\end{abstract}

Keywords: Moderating, Government policy, Strategic leadership, Performance, County Governments.

\section{Introduction}

Strategic leadership is the ability of influencing others to voluntarily make decisions that enhance the prospects for the organization's long-term success while maintaining long-term financial stability and performance (Paine, 2015). Globally the business world is changing more rapidly and more dramatically than ever before; technology, globalization, and competition have fundamentally reshaped the business environment. To deal with such a complex and dynamic environment, organizations need experienced people with welldeveloped leadership abilities and acumen (Ministry of state for planning and National Development, 2014).

In developing countries in Africa, leaders who are constitutionally assigned to manage the public sector and ensure the government performs as per the electorate expectation formulate the organization's goals and strategies, develop structures, processes, communication and core competencies, manage multiple constituencies,

*Corresponding author's ORCID ID: 0000-0002-7802-8383 DOI: https://doi.org/10.14741/ijmcr/v.6.5.17 choose key executives, groom the next generation of executives, provide direction with respect to the public sector strategies, maintain an effective culture building competence and serve as the representative of the organization to government and other organizations and constituencies as well as negotiate with them (Collins, 2015). Such strategic leadership must be able to deal with ambiguity, complexity, and information overload requiring adaptability and a sense of timing (Bonoff and Zimmerman, 2014).

In the Kenyan context, the strategic leadership capability emphasis on the new constitution promulgated on $27^{\text {th }}$ August, 2010. For instance, the appointment to senior positions in the government requires one to have personal integrity, competence and suitability (RoK, 2012). Other challenges include lack of strategic planning skills, budgeting, staffing, governing structure, growth and change management among others (Oloo, 2016). It is evident that people who do not know what the problem is and how to deal with it cannot address these challenges. Hence the need for strategic leadership thus the need for this study. 
The primary focus of Transformational Leadership Theory, Schein's Theory, Dynamic Capability Model and The Higgins's Eight (8) S Model is the fact that the counties should interact with their environment as much as it is necessary. Within the frame of the four theories, organizational needs to access environmental resources, emerge as a vital issue for the survival (Michelle and Duffy, 2014). Counties are considered as an open system that is dependent on the national government for the provision of important resources (Ndegwa, 2014). It is assumed that the performance of the counties is based on their abilities to provide and control the internal and external resources and therefore to find an interaction with the government policy which is key to the study.

\subsection{Statement of the Problem}

County governments in the North Rift Region of Kenya after devolution are still left behind in-terms of undertaking major infrastructural projects and serving the general public well a reason that can only be associated with poor leadership. This is after having a five-year county integrated development plan in place. The challenge has resulted to astand still in development, something that has left many people doubting the usefulness of devolution (Koigi, 2014). Counties in the North Rift experience strategic leadership challenges as a result of inability of inexperienced, senior leaders who lack wisdom and vision to create and execute plans and make consequential decisions in the volatile, uncertain, complex and ambiguous strategic environment (Muia, 2015).

One of the strategic goals of the National Government for the year 2012 was to enhance devolution in all sectors in Kenya (Afrobarometer, 2014). While the study appreciates the extent of Kenya's devolution of authority to various tiers of the local government, the level of empowerment through democratization, participation, accountability, responsibility and efficiency, effective use of resources is still a big debate. Statistics show that $67 \%$ of the counties in the North Rift part of Kenya- in a survey conducted by World Bank (2015) were likely to achieve their strategic goals due to good strategic leadership from the top management.

However, a local report by KNBS (2016) shows that devolution at the county levels in the in North Rift Region has failed to implement up to $70 \%$ of their strategic initiatives. The performance failure has been hampered by persistent pressure from stakeholders for greater profitability, increased complexity of the county governments, difficult challenge faced by executives, low levels of participation of a large number of county managers across all functions at an early stage of executing strategy, difficulty of securing the required resources to execute the strategy and executives know more about strategy formulation than strategy implementation (MPN\&D, 2015).
The researcher notes that government polices influence the performance of the counties which is attributed to insufficient amount of funding, disbursement period of the funds which is bureaucratic, and funds takes time to get to the county accounts as well as some counties being densely populated thus the funds allocated are not sufficient as well. This influenced the leadership of the North Rift counties, which poses the tougher more timeconsuming management, challenge and practitioners are emphatic in saying that it is a whole lot easier to develop a sound strategic plan than it is to 'make it happen'. Enormous time, energy, and resources go to policy implementation, but the counties in the North Rift have little to show for the effort, largely due to poor implementation as noted in local studies by Kibua and

Mwabu (2016) Mwangi (2014) and Mutuiri (2015).

Strategic leadership in devolution is a relatively new development in the country. Empirical studies on the behavior of this phenomenon both at the national and county levels are yet to be initiated. This lacks authentic empirical evidence to enhance management of public affairs in era of the new constitutional dispensation in Kenya. However, concerns are beginning to be registered raising the need for the study relating to strategic leadership in devolution from an academic point of view. Thus, the purpose of this study is to establish the effects of strategic leadership, government policies and performance of county governments in North Rift Region, Kenya.

\subsection{Specific Objectives}

The specific objective of the study was to;

To determine the moderating effect of government policy on strategic leadership and performance of county governments in North Rift Region, Kenya.

\section{Study Hypotheses}

$\mathrm{H}_{0}$ : There is no significant moderating effect of government policy on strategic leadership and of performance county government in North Rift Region, Kenya.

\section{Literature review}

\subsection{Theoretical Review}

The first theory is Transformational Leadership Theory which is the study's main theory. The theory focuses on aspects of leadership mainly; coordination skills and mode of execution in an organization. Schein's Theory compliments Transformational Leadership Theory by presenting aspects of culture building as a competence. The main aspects discussed under Schein's Theory in culture are norms and systems in a county aspects to enhance performance. Dynamic Capability Model is the 
third theory which compliments Transformational Leadership Theory. This theory is contextualized to strategy communication competence aspects which include channels of communication used and feedback action within an organization. The last theory is Higgins's Eight (8) S Model which addresses the resource management competence aspects mainly HR competency and evaluation systems used in an organization. The organization here is the county government which its performance is being evaluated thus the adoption of the four theories.

\subsection{Strategic Leadership and Performance}

There a few formal definitions of the concept of strategic leadership in the literature. Harrington (2014) suggested that strategic leadership involves a synergistic combination of visionary and managerial leadership to influence those with whom they work with to make decisions on a voluntary basis. Ojo (2013) stated that strategic leadership is an extremely complex but critical form of leadership. According to these authors, strategic leadership is multifunctional, involves managing through others, and helps county government to cope with change that seems to be increasing exponentially in the contemporary business environment.

According to Johnson (2015) strategic leadership requires the ability to integrate both internal and external business environments of the county government, and to manage and engage in complex information processing. Strategic leadership is therefore the leader's ability to envision, anticipate and maintain flexibility and to empower others to create strategic change as necessary (Hubbard, Samuel and Heaps, 2014). Strategic leadership demands leaders to develop and communicate the county government purpose (vision); tactfully organise the human resource capabilities and competencies with the task at hand; exercise high intensity of integrity and ethical standards; deliver extraordinary performance; and sustain a competitive advantage. These elements exist in dynamic tension, each demanding the leader's time and energy.

Crossan and Bedrow (2013) assert that there are several identifiable actions that characterize strategic leadership that positively contributes to effective use of the firm's strategies. These actions are: managing the firms resources effectively (includes developing human capital), establishing a strategic direction, fostering an effective culture, exploiting core competencies using effective county government control systems, and establishing ethical practices. In general, the concept of county government performance is based upon the idea that an organization is the voluntary association of productive assets, including human, physical, and capital resources, for the purpose of achieving a shared purpose (Vandenberg, Richardson and Eastman, 2015). Those providing the assets were only to commit them to the county government so long as they are satisfied with the value they receive in exchange, relative to alternative uses of the assets. As a consequence, the essence of performance is the creation of value.

Johnson (2015) points out that so long as the value created by the use of the contributed assets is equal to or greater than the value expected by those contributing the assets, the assets should continue to be made available to the organization and the county government should continue to exist. Therefore, value creation, as defined by the resource provider, is the essential overall performance criteria for any organization. The role of leadership is of fundamental importance to the performance and success of the county government. This includes many aspects like; visionary, motivator, enabler, facilitator as well as mentor and coach (Collins, 2015).

DiMaggio and Powell (2014) highlights that at the start-up stage of a business organization, the managing director or leader is responsible for the supply of the product or service, the administration, the management and the sales and marketing. In effect the business is the leader and the leader is the business. As the business grows, the leader has to concentrate on the overall strategic direction and delegate some of the operational and technical decisions to appointed staff and employees. The leader has to give responsibility on the basis of trust or design control systems to monitor individual activity. The leader will now also have to employ management and staff with the necessary specialist skills. In order for the business to grow, sales revenue must increase which means that more products are manufactured or quality is improved to justify an increased unit price or product range (Paine, 2015).

Teece (2012) stated that a leader must also understand the critical interplay between capabilities and value creation, a relationship that goes to the heart of high performance in county government (Bourgeois and Bodwin, 2015). To create value, each high performing county develops a formula for doing business - either at the enterprise or business unit level - that successfully translates a big idea regarding customer needs into a unique set of connected business processes and resources that cost-effectively satisfy those needs. Innovation and talent management are also two of the essential capabilities needed for high performance in the county government. The investment in training and leadership development to enhance innovation and the development of talent has been observed as a crucia strategic focus in high-performing counties (Mitullah, 2014).

Turnbull (2014) posits that to manage the dynamic balance between the organisation, its people and the demands of a complex unstable environment, the strategic leader needs to enable the organisation to engage in a relevant and dynamic way with its environment. This requires leaders capable of building an organisation designed to attract develop and retain the best talent (O'Toole and Bennis 2014). It also demands leaders who are capable of aligning people across the 
organisation with an uncompromising customer focus which informs the organisational systems, structure and strategic decisions. The strategic leader's personal integrity and intensity is a powerful driver of organisational energy and direction. However, left unchecked, the leader's personality and drive can overwhelm or suppress input and engagement more widely in the organisation. The strategic leader needs to create an environment where people willingly engage their passion, creativity, imagination and unique motivations to generate the financial results required by the business (Stogdill and Coons, 2015).

The above review shows that little has been done to evaluate how strategic leadership influence on the performance of County Governments. This study therefore adds to existing knowledge and was conducted in Kenya precisely in the North Rift region with emphasis on performance of County Governments in the existing national policy framework.

\section{Methodology}

\subsection{Philosophical orientation}

This study was approached from a positivism philosophy point of view. According to Kombo and Tromp (2000), the positivism school of thought was grounded on the philosophy that only one reality exists though can only be known imperfectly due to human limitations and researchers can only discover this reality within the realm of probability.

\subsection{Research Design}

Triangulation approach was adopted for the study. The study adopted both explanatory and descriptive crosssectional survey design. The study was conducted in seven counties based in Northern Kenya and include; Turkana, Uasin Gishu, Nandi, Elgeyo Marakwet, West Pokot, Baringo and Transnzioa (IEBC, 2016).The target population included Governors and their Deputies, County Secretaries and their Deputies, County Public Secretaries, County Executive Committee (CEC) from each county, County Officers (COs) and Directors in the seven counties which were selected for the study totaling to 539.

\subsection{Sample Size Design Procedure and Sampling Technique}

For this study a sample of 230 was arrived at. The researcher used stratified random sampling technique to select the study participants. The governors or their deputies were purposively selected while the rest of the study respondents were selected using simple random sampling technique.

\subsection{Data Collection Instrument and Procedure}

Primary and secondary data were collected by use of selfadministered closed and open ended questionnaires and interview schedules. Validity and Reliability of the instruments were tested using content validity and Cronbach's Alpha of 0.812 was computed

\subsection{Data Analysis}

The study employed descriptive and inferential statistical analysis including simple and hierarchical regression model, Pearson correlation analysis was also conducted (Chandran, 2003). Hierarchical and stepwise regression models were adopted in the study to test the relationship between County government performance (dependent variable) and strategic leadership (independent variable). The researcher used the above model to ascertain the causal effect of the independent variables upon the dependent variable.

$Y=\beta_{0}+\beta_{1} X_{1} M+\beta_{2} X_{2} M+\beta_{3} X_{3} M+\beta_{4} X_{4} M+\varepsilon$.....Model (i) (Hierarchical model to determine the moderating effect of government policy on relationship between strategic leadership and performance of county government)

Where:

$\mathrm{Y}=$ Dependent variable (Performance)

$X=$ Independent variables (strategic leadership)

$\beta_{0}=$ Constant term

$\mathrm{X}_{1}=$ Leadership capacity

$\mathrm{X}_{2}=$ Culture building competence

$X_{3}=$ Strategic communication competence

$\mathrm{X}_{4}=$ Resource management competence

$\mathrm{M}=$ Moderator (Allocation policy, Approval policy and Disbursement policy)

e $=$ Error term (standard error)

\section{Results and discussions}

4.1 Government Policies, strategic leadership practices and county government performance

The research asked the respondents to state whether their government policies influence strategic leadership practices and performance in the county. 
Table 4.1: Government Policies, strategic leadership practices and county government performance

\begin{tabular}{|c|c|c|c|c|c|c|}
\hline & $\mathrm{N}$ & Mean & \multicolumn{2}{|c|}{ Skewness } & \multicolumn{2}{|c|}{ Kurtosis } \\
\hline & Statistic & Statistic & Statistic & $\begin{array}{l}\text { Std. } \\
\text { Error }\end{array}$ & Statistic & $\begin{array}{l}\text { Std. } \\
\text { Error }\end{array}$ \\
\hline $\begin{array}{l}\text { Late disbursement of funds to the county by the national } \\
\text { government affects county leadership ability to deliver services to } \\
\text { the citizens }\end{array}$ & 206 & 3.8107 & -.723 & .169 & -.315 & .337 \\
\hline $\begin{array}{c}\text { County leadership have requisite skills on the approval of funds } \\
\text { before allocation }\end{array}$ & 206 & 3.4369 & -.445 & .169 & -.042 & .337 \\
\hline $\begin{array}{l}\text { Disbursement policy of funds in the county affects the leadership } \\
\text { ability for service delivery to citizens }\end{array}$ & 206 & 3.3883 & -.215 & .169 & -.518 & .337 \\
\hline $\begin{array}{l}\text { Funds allocation to expenditures rather than development } \\
\text { hinders county performance }\end{array}$ & 206 & 3.3447 & -.088 & .169 & -.675 & .337 \\
\hline $\begin{array}{l}\text { Bureaucracy in funds approval is as a result of leadership } \\
\text { incompetencies in the county }\end{array}$ & 206 & 3.3155 & -.120 & .169 & -.365 & .337 \\
\hline Disbursement policy in the county is based on priority areas & 206 & 3.3010 & -.193 & .169 & -.612 & .337 \\
\hline $\begin{array}{l}\text { Elaborate policy of allocating funds for resource management, } \\
\text { leadership training and cultural activities }\end{array}$ & 206 & 3.2524 & -.225 & .169 & -.260 & .337 \\
\hline $\begin{array}{l}\text { Adequate allocation of funds by national government enables the } \\
\text { county build the capacity of its staff }\end{array}$ & 206 & 3.2049 & .010 & .170 & -.622 & .338 \\
\hline Valid N (list wise ) & 206 & & & & & \\
\hline
\end{tabular}

Source: Field data (2018)

From the study findings in Table 4.1, it can be deduced that: Late disbursement of funds to the county by the national government affects county leadership ability to deliver services to the citizens due to a greater extent response with a mean of 4 with a Skewness value of 0.723 and Kurtosis value of -0.315 showing a normal distribution. The results also show that, County leadership have requisite skills on the approval of funds before allocation, this was confirmed by the moderate extent of the mean and the Skewness value of -0.445 and Kurtosis of -0.042 illustrating a normal distribution.

The study also found out that, disbursement policy of funds in the county affects the leadership ability for service delivery to citizens, this was affirmed with a moderate extent mean of 3 and a Skewness value of 0.215 and Kurtosis value of -0.518 showing that the responses were normally distributed. It can also be observed that to a moderate extent, funds are allocated for expenditures rather than for development thus hindering county performance as confirmed with a mean of 3 and Skewness value of -0.088 and a Kurtosis value of -0.675 depicting a normally distributed. Bureaucracy in funds approval as a result of leadership incompetency in the county was moderate (mean=3) with a Skewness value of -0.120 and Kurtosis value of -0.365 showing normally distributed responses.

The study findings observed that disbursement policy in the county is based on priority areas to a moderate extent (mean=3) and a Skewness value of -0.193 and Kurtosis value of -0.612 . The respondents also expressed a moderate satisfaction on the elaborate policy of allocating funds for resource management, leadership training and cultural activities with a Skewness value of 0.225 and Kurtosis value of -0.260 depicting normal distributed responses. Finally, the study findings indicated that adequate allocation of funds by national government enables the county build the capacity of its staff to a moderate extent (mean=3) and a Skewness value of 0.010 and a Kurtosis value of -0.622 depicting a normaly distributed responses.

In general, it can be deduced that government policies affect, to a moderate extent, the effectiveness of the leaders operations having a greater bearing on the performance of the county. These findings results stress the importance of government policy for improved county government performance as highlighted by past studies conducted by Michelle and Duffy (2014) and Neely et al. (2014).Michelle and Duffy (2014) assert that, service delivery was centralized, with the centra government delegating some functions to provincial level and local authorities (LAs).

Through the interview conducted, one of the governor opined that,

"For the counties to be effective, the national government needs to do the following: Timely disbursement of funds to the county; respect for the constitutional mandates; and empowerment of county assemblies and senate to support devolution through constitutional changes".

Source: Interview by researcher (2018) 
Table 4.2: Strategic leadership and county government performance

\begin{tabular}{|c|c|c|c|c|c|c|}
\hline & \multirow{2}{*}{$\begin{array}{c}\mathrm{N} \\
\text { Statistic }\end{array}$} & \multirow{2}{*}{$\begin{array}{c}\text { Mean } \\
\text { Statistic }\end{array}$} & \multicolumn{2}{|c|}{ Skewness } & \multicolumn{2}{|c|}{ Kurtosis } \\
\hline & & & Statistic & $\begin{array}{l}\text { Std. } \\
\text { Error }\end{array}$ & Statistic & $\begin{array}{l}\text { Std. } \\
\text { Error }\end{array}$ \\
\hline Good leadership in the county leads to an effective expenditure management & 206 & 3.7427 & -.720 & .169 & -.051 & .337 \\
\hline $\begin{array}{c}\text { Reduces bureaucracy in funds approval is an important ingredient towards } \\
\text { better performance }\end{array}$ & 206 & 3.6262 & -.427 & .169 & -.541 & .337 \\
\hline Better county communication channel is an ingredient to better performance & 206 & 3.6214 & -.531 & .169 & .017 & .337 \\
\hline Culture enhances the county performance & 206 & 3.5437 & -.115 & .169 & 0.056 & .337 \\
\hline $\begin{array}{l}\text { Effective leadership at county promotes facilitation and coordination of citizen } \\
\text { participation }\end{array}$ & 206 & 3.4951 & -.173 & .169 & -.394 & .337 \\
\hline $\begin{array}{l}\text { Leadership in the county is competent to implement devolved governance } \\
\text { thus increase performance }\end{array}$ & 206 & 3.4709 & -.430 & .169 & .297 & .337 \\
\hline Citizen of my county are satisfied with the current leadership & 206 & 3.4612 & -.328 & .169 & -.546 & .337 \\
\hline $\begin{array}{l}\text { National government faster disbursement of funds to the county increase } \\
\text { performance }\end{array}$ & 206 & 3.2573 & -.075 & .169 & -.814 & .337 \\
\hline $\begin{array}{l}\text { Revenue collection has increased in the last five years in the county due to } \\
\text { competent leaders }\end{array}$ & 206 & 3.2573 & -.241 & .169 & -.307 & .337 \\
\hline Human capital is fully developed to support developed governance strategy & 206 & 3.1602 & -.059 & .169 & -.008 & .337 \\
\hline Valid N (listwise) & 206 & & & & & \\
\hline
\end{tabular}

Source: Field data $(2018$

\subsection{Strategic leadership and county government performance}

The researcher asked the respondents to state whether strategic leadership practices have a bearing on county government performance. Table 4.2 illustrates the study findings.

Study findings in Table 4.2 can be interpreted as: Respondents agreed to a greater extent (mean=4) that good leadership in the county leads to an effective expenditure management and their responses were also normally distributed with a Skewness value of -0.720 and Kurtosis value of -0.051 . Reduced bureaucracy in funds approval was also found to be an important ingredient towards better performance with a greater extent (mean $=4$ ) and a Skewness value of -0.427 and a Kurtosis value of -0.541 depicting a normal distributed responses. The results also indicate that better county communication channel is an ingredient to better performance to a greater extent (mean=4) and a Skewness value of -.531and a Kurtosis value of 0.017 depicting normally distributed responses. Findings from the study shows that culture enhances the county performance and improves county image and allows employees to perform their job well to a great extent (mean=4) with a Skewness value of -.115 and Kurtosis value of 0.056 illustrating normally distributed responses. With regard to effective leadership at county promoting facilitation and coordination of citizen participation, it was supported by the moderate extent (mean=3) and
Skewness value of -0.173 and Kurtosis value of -0.394 depicting normaly distributed responses.

The study results depict to a moderate extent (mean=3) that leadership in the county is competent to implement devolved governance thus increase performance with a Skewness value of -0.430 and Kurtosis value of 0.297 meaning that the responses were normally distributed. Citizen satisfaction with the current leadership was also moderately evident (mean=3) with a Skewness value of -0.328 and Kurtosis value of -0.546 depicting normally distributed responses.

National government's faster disbursement of funds to the county was also found to a moderate extent (mean=3) to increase county performance with a Skewness value of -.075 and Kurtosis value of -0.814 thus normally distributed responses. Respondents were moderately satisfied (mean $=3$ ) that revenue collection has increased in the last five years in the county due to competent leaders with a Skewness value of -0.241 and Kurtosis value of -0.307 illustrating normally distributed responses. Lastly, the respondents also were to a moderate extent (mean=3) in agreement that human capital if fully developed and can support county governance strategy with a Skewness value of -0.059 and Kurtosis value of -0.008 depicting normally distributed responses.

In general it can be deduced that strategic leadership practices and favourable government practices lead to performance of the county government. This was also affirmed through the interview with county governors. One of the governors said; 
"Efficiency and timeliness in the disbursement of funds by the national government enables us to increase county performance. This will in turn lead to building of our staff capacity through training on proper resource management".

Source: Interview by researcher (2018)

The results in Table 4.2 are consistent with the past studies carried out by Mahmoud and Yusif (2012) that found out that County Governments are in the business of meeting the needs of their customers and other stakeholders. This is also supported by O'Reilly, Caldwell, Chatman, Lapiz and Seif (2010) who acknowledged that leaders' effectiveness was significant in performance improvement. This view is also agreeable with the study by Ojokuku, Odetayo and Sajuyigbe (2012) who found that leadership predicts organizational performance. Similarly, a study by Riaz and Haider (2010) observed that effective leadership plays an important role in the growth and performance of an organization.

\subsection{Inferential Statistical Analysis}

4.4 Moderating effect of government policy on the relationship between strategic leadership and performance of county governments

Findings in Tables 4.3-4.4 show the correlation between strategic leadership, government policy and performance of county governments without government policy. The tables were used to answer to the study fifth objective, that is, to investigate the moderating effect of government policies on strategic leadership and performance of county governments in North Rift Region, Kenya.

Table 4.3: Correlation without government policy

\begin{tabular}{|c|c|c|}
\hline & & County Government Performance \\
\hline & Pearson Correlation & $.208^{* *}$ \\
\hline \multirow[t]{3}{*}{ Leadership capacity Competence } & Sig. (2-tailed) & .003 \\
\hline & $\mathrm{N}$ & 206 \\
\hline & Pearson Correlation & $.331^{* *}$ \\
\hline \multirow[t]{3}{*}{ Culture building Competence } & Sig. (2-tailed) & .000 \\
\hline & $\mathrm{N}$ & 206 \\
\hline & Pearson Correlation & $.384^{* *}$ \\
\hline \multirow[t]{3}{*}{ Strategic Communication Competence } & Sig. (2-tailed) & .000 \\
\hline & $\mathrm{N}$ & 206 \\
\hline & Pearson Correlation & $.327^{* *}$ \\
\hline \multirow[t]{2}{*}{ Resource Management Competence } & Sig. (2-tailed) & .000 \\
\hline & $\mathrm{N}$ & 206 \\
\hline
\end{tabular}

Results in Table 4.3 show that in absence of government policy, each strategic leadership constructs are positively and significantly related to performance of county government at $99 \%$ confidence level. Strategic communication competence had the highest positive and significant relationship with performance of county government $(r=0.384, \alpha=0.000$ and $p$-value $=0.01$ thus $\alpha<p$-value) followed by resource management competence $(r=0.327, \alpha=0.000$ and $p$-value $=0.01$ thus $\alpha<p$-value) followed by culture building competence ( $r=0.331, \alpha=0.000$ and $p$-value $=0.01$ thus $\alpha<p$-value) and leadership capacity $(r=0.208, \alpha=0.003$ and $p$-value $=0.01$ thus $\alpha<p$-value).

Therefore, from the study, there exists statistically significant positive relationship among all the constructs of strategic leadership and performance of County Government in the North Rift Region, Kenya. The results in Table 4.3 are consistent with the past studies carried out by Mahmoud and Yusif (2012) that found out that County Governments are in the business of meeting the needs of their customers and other stakeholders. This is also supported by O'Reilly, Caldwell, Chatman, Lapiz and Seif (2010) who acknowledged that leaders' effectiveness was significant in performance improvement. This view is also agreeable with the study by Ojokuku, Odetayo and Sajuyigbe (2012) who found that leadership predicts organizational performance. Similarly a study by Riaz and Haider (2010) observed that effective leadership plays an important role in the growth and performance of an organization. 
Table 4.4: Correlation with government policy

\begin{tabular}{ccc}
\hline & & County Government Performance \\
\hline LCGP & Pearson Correlation & $.330^{* *}$ \\
& Sig. (2-tailed) & .000 \\
& $N$ & 205 \\
CBCGP & Pearson Correlation & $.413^{* *}$ \\
& Sig. (2-tailed) & .000 \\
& $N$ & 205 \\
SCCGP & $N$ & $.456^{* *}$ \\
& Pearson Correlation & .000 \\
& Sig. (2-tailed) & 205 \\
RMCGP & $\mathrm{N}$ & $.427^{* *}$ \\
& Pearson Correlation & .000 \\
& Sig. (2-tailed) & 205 \\
\hline & $N$ & \\
& $* *$ Correlation is significant at the 0.01 level (2-tailed). \\
& Source: Field data (2018)
\end{tabular}

Key: GP= Government policy, $\mathrm{LC}=$ Leadership capacity, $\mathrm{CBC}=$ Culture building competence, $\mathrm{SCC}=$ Strategic communication competence, and $\mathrm{RMC}=$ Resource management competence

Table 4.5: Hierarchical regression results on strategic leadership, government policy and county government performance

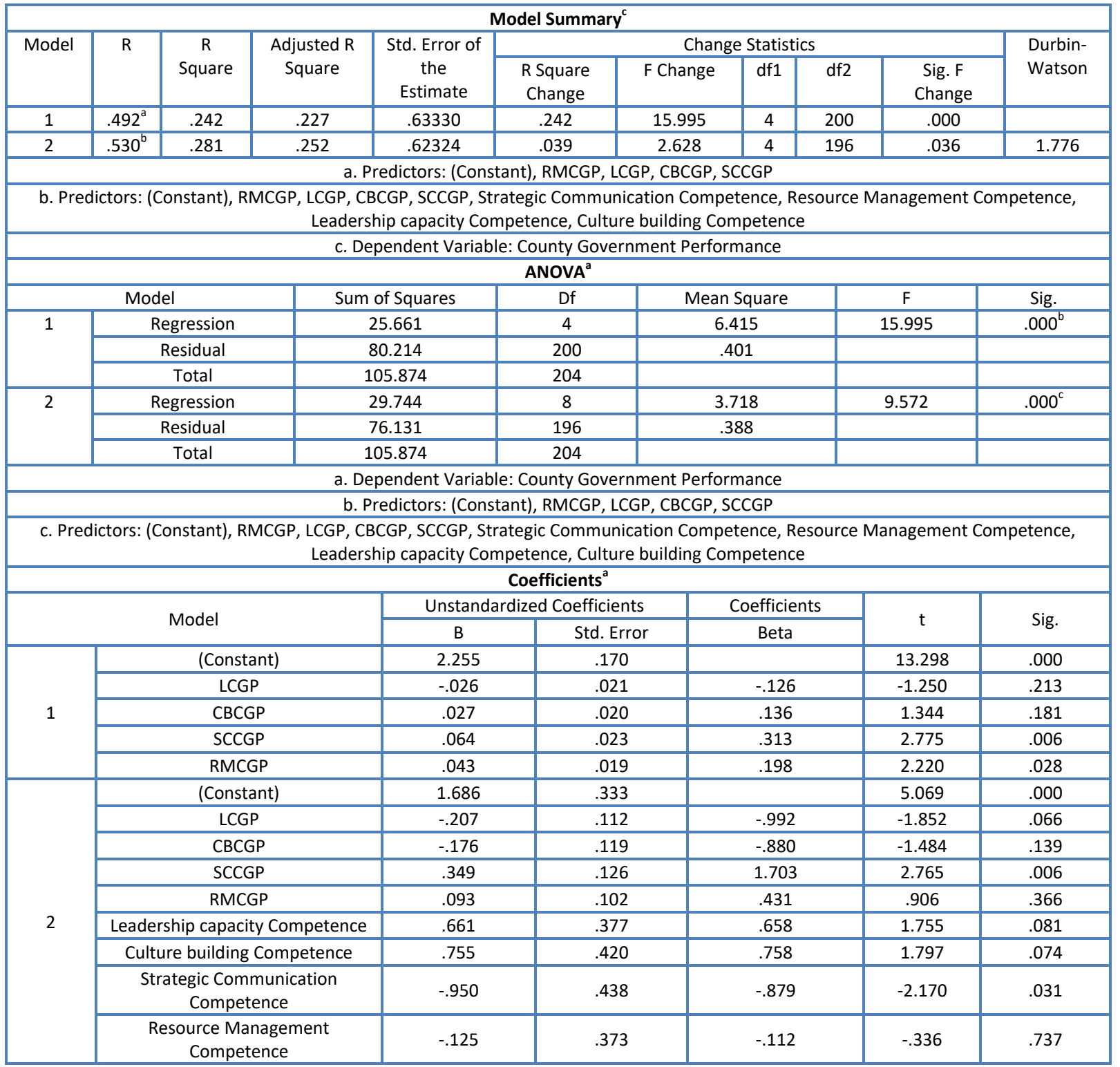

a. Dependent Variable: County Government Performance

Source: Field Data (2018)

Key: $\mathrm{GP}=$ Government policy, $\mathrm{LC}=$ Leadership capacity, $\mathrm{CBC}=$ Culture building competee, $\mathrm{SCC}=$ Strategic communication competence, and $\mathrm{RMC}=$ Resource management competence 
Study findings in Table 4.4 show that in the presence of government policy, each strategic leadership constructs is highly positively and significantly related to performance of county governments at $99 \%$ confidence level. Strategic communication competence and government policy had the highest positive and significant relationship with performance of county governments ( $r=0.456, \alpha=0.000$ and $p$-value $=0.01$ thus $\alpha<p$-value) followed by resource management competence and government policy ( $r=0.427, \alpha=0.000$ and $p$-value $=0.01$ thus $\alpha<p$-value), followed by culture building competence and government policy ( $r=0.413, \alpha=0.000$ and $p$-value $=0.01$ thus $\alpha<p$ value) and lastly leadership capacity and government policy ( $r=0.330, \alpha=0.000$ and $p$-value $=0.01$ thus $\alpha<p$ value).Comparing the results in Table 4.3 and Table 4.4 , it is evident that when government policy is involved, the correlation between strategic leadership and performance of county government improves greatly. It can be concluded that government policy plays an important role in moderating the effects of strategic leadership and performance of county government. For a higher county government performance to be realized, government policy on disbursement, allocation and approval of funds need to be improved. These findings results stress the importance of government policy for improved county government performance as highlighted by past studies conducted by Michelle and Duffy (2014) and Neely et al. (2014).

Michelle and Duffy (2014) assert that, service delivery was centralized, with the central government delegating some functions to provincial level and local authorities (LAs). Policies were implemented and functions performed on behalf of the central government and therefore performance measurement was for the central government. With the new regime of decentralization, government operations have been decentralized as per the fourth schedule of Constitution, making counties responsible for setting operational policies for enabling them perform the decentralized operations. Operational policies are the instruments and practices by which county governments rationalize and continuously improve the work they do through available knowledge and technology (Neely et al., 2014).

Hierarchical regression analysis of government policy on relationship between strategic leadership and county government performance

A hierarchical multiple regression was performed in this study to ascertain whether government policy has any significant contribution to strategic leadership and performance of county governments in the North Rift Region. Table 4.5 shows the results of the regression analysis.

From Table 4.5, the results in the model summary show that when government policy is introduced in the model of strategic leadership and performance of county government, there is an increase in the value of $R$ and $R^{2}$. The $\mathrm{R}$ changed from .492 to .530 , implying that government policy causes a strong positive and significant relationship between strategic leadership and performance of county government at $95 \%$ confidence level $(R=0.530, \alpha=0.036$ and $p$-value $=0.01$ thus $\alpha<p$ value). It is also observed that the $R^{2}$ changed from .242 to .281 implying that introduction of government policy to strategic leadership accounts for $28.1 \%$ of the variation of county government performance as opposed to the absence of government policy that leads to only $24.2 \%$ of the variation in the performance of county government. In general, from the model summary, it can be concluded that government policy plays a significant moderating effect on the relationship between strategic leadership and performance of county government.

The analysis of variance (ANOVA) tests for the hierarchical regressions showed the following F-ratio results: In first model, in the first step of hierarchical multiple regression for one predictor variable the results of $F=15.995 ; p<.05$. In step 2 , after entry of government policy the results of $F=9.572 ; p<.05)$. Since the F-statistics results are significant, the regression model is deemed fit to be used for analysis involving strategic leadership, government policy and performance of county government.

Regression Coefficient results in Table 4.5 reveal to which extent strategic leadership, government policy predict performance of county government. Based on the study results, the equation for multiple linear regression model was in the form of;

\section{$Y=2.255-0.026 X_{1} M+0.027 X_{2} M+0.064 X_{3} M+0.043 X_{4} M+e$.}

Where $X_{1} M=$ Leadership capacity*Government policy, $\mathrm{X}_{2} \mathrm{M}=$ Culture building competence* Government policy, $\mathrm{X}_{3} \mathrm{M}=$ Strategic communication competence* Government policy and $\mathrm{X}_{4} \mathrm{M}=$ Resource management competence* Government policy. Beta coefficients for the variables $\left(X_{1} M, X_{2} M, X_{3} M\right.$ and $\left.X_{4} M\right)$ measure the number of units of strategic leadership and government policy lead to a corresponding 1 unit in performance of county government.

The results in Table 4.5 also show that only strategic communication competence, resource management competence and government policy are statistically significant ( $\alpha=0.006 ; \alpha=0.028$ and $p$-value $=0.05$ thus $\alpha<p$ value) while leadership capacity, culture building competence and government policy are statistically insignificant $(\alpha=0.213, \alpha=0.181$ and $p$-value $=0.05$ thus $\alpha>p$-value) respectively. This implies strategic communication competence and resource management competence contributes significantly to county government performance provided government policy for fund disbursement, allocation and approval is in place.

The results of the regression in Table 4.5 were used to test the fifth research hypothesis, "Ho: There is no 
moderating effect of government policies on strategic leadership and county government performance". The null hypothesis of the study was therefore rejected at 0.05 significant level since the beta values t-statistics was significant $(\alpha=0.000)$. The study thus concluded that government policy has a positive and significant effect on the relationship between strategic leadership and county government performance in the North Rift Region.

These findings results stress the importance of government policy for improved county government performance as highlighted by past studies conducted by Michelle and Duffy (2014) and Neely et al. (2014).Michelle and Duffy (2014) assert that, service delivery was centralized, with the central government delegating some functions to provincial level and local authorities (LAs). Policies were implemented and functions performed on behalf of the central government and therefore performance measurement was for the central government. With the new regime of decentralization, government operations have been decentralized as per the fourth schedule of Constitution, making counties responsible for setting operational policies for enabling them perform the decentralized operations. Operational policies are the instruments and practices by which county government rationalize and continuously improve the work they do through available knowledge and technology (Neely et al., 2014).

\section{Conclusion and recommendations}

\subsection{Strategic leadership practices, government policy and county government performance}

From the study findings, it can be deduced that: Late disbursement of funds to the county by the national government affects county leadership ability to deliver services to the citizens due to a greater extent response with a mean of 4 . The results also show that, County leadership has requisite skills on the approval of funds before allocation, this was confirmed by the moderate extent of the mean of 3 . The study also found out that, disbursement policy of funds in the county affects the leadership ability for service delivery to citizens, this was affirmed with a moderate extent mean of 3 . It can also be observed that funds are allocated to expenditures rather than development thus hindering county performance as confirmed by a moderate extent mean of 3 . Bureaucracy in funds approval as a result of leadership incompetency in the county was moderate (mean=3). The study findings observed that disbursement policy in the county is based on priority areas to a moderate extent (mean=3). The respondents also expressed a moderate satisfaction on the elaborate policy of allocating funds for resource management, leadership training and cultural activities.

Finally, the study findings indicated that adequate allocation of funds by national government enables the county build the capacity of its staff to a moderate extent (mean=3). In general, it can be deduced that government policies affect, to a moderate extent, the effectiveness of the leaders operations having a greater bearing on the performance of the county. Through the interview $s$ conducted, one of the governor opined that for their counties to be effective, the national government need to do the following: Timely disbursement of funds to the county; Respect for the constitutional mandates; and Empowerment of county assembly and senate to support devolution through constitutional changes.

Study findings were interpreted as: Respondents agreed to a greater extent (mean $=4$ ) that good leadership in the county leads to an effective expenditure; Reduced bureaucracy in funds approval was also found to be an important ingredient towards better performance with a greater extent (mean=4). ; The results also indicate that better county communication channel is an ingredient to better performance to a greater extent (mean=4). Findings from the study shows that culture enhances the county performance and improves county image and allows employees to perform their job well to a great extent (mean=4). As regards effective leadership at county level promoting facilitation and coordination of citizen participation, it was supported by the moderate extent (mean=3). Results illustrated to a moderate extent $($ mean $=3)$ that leadership in the county is competent to implement devolved governance thus increased performance. Citizen satisfaction with the current leadership was also moderately evident (mean=3). National government faster disbursement of funds to the county was also found to a moderate extent (mean=3) to increase county performance. Respondents were moderately satisfied (mean=3) that revenue collection has increased in the last five years in the county due to competent leaders. Lastly, the respondents were also to a moderate extent (mean=3) in agreement that human capital, if fully developed, can support county governance strategy. In general, it can be deduced that strategic leadership practices and favourable government practices leads to performance of the county government. This was also affirmed through the interview with county governors. One of the governors said that efficiency and timeliness in the disbursement of funds by the national government enables them to increase county performance. This will in turn lead to building of staff capacity through training on proper resource management.

The study correlational results showed that in the absence of government policy, each strategic leadership construct is positively and significantly related to performance of county government at $99 \%$ confidence level. Strategic communication competence had the highest positive and significant relationship with performance of county government followed by resource management competence; culture building competence and leadership capacity. Therefore, from the study, there exists statistically significant positive relationship among all the constructs of strategic leadership and performance of County Governments in North Rift Region, Kenya. 
Study findings on correlation showed that in the presence of government policy, each strategic leadership constructs is highly, positively and significantly related to performance of county governments at $99 \%$ confidence level. Strategic communication competence and government policy had the highest positive and significant relationship with performance of county governments followed by resource management, competence and government policy; culture building competence and government policy and lastly leadership capacity and government policy.

Comparing the results in the presence and absence of government policy, it is evident that when government policy is involved, the correlation between strategic leadership and performance of county government improves greatly. It can be concluded that government policy plays an important role in moderating the effects of strategic leadership and performance of county government. For a higher county government performance to be realized, government policy on disbursement, allocation and approval of funds need to be improved.

From the results on summary of model, it shows that when government policy is introduced in the model of strategic leadership and performance of county government, there is an increase in the value in the value of $R$ implying that government policy causes a strong positive and significant relationship between strategic leadership and performance of county government at 95\% confidence level. It is also observed that the R2 changed from .242 to .281 , implying that introduction of government policy to strategic leadership accounts for $28.1 \%$ of the variation of county government performance as opposed to absence of government policy that lead to only $24.2 \%$ of the variation in the performance of county government. In general, from the model summary, it can be concluded that government policy plays a significant moderating effect on the relationship between strategic leadership and performance of county government.

The analysis of variance (ANOVA) indicated F-statistics significant results thus the regression model was deemed fit to be used for analysis involving strategic leadership, government policy and performance of county government. Based on regression coefficient results indicated that increase in use of strategic leadership and government policy lead to a corresponding 1 unit in performance of county government.

The results of the study also showed that only strategic communication competence, resource management competence and government policy are statistically significant while leadership capacity, culture building competence and government policy are statistically insignificant. This implies strategic communication competence and resource management competence contributes significantly to county government performance provided government policy for fund disbursement, allocation and approval is in place. As a result of the study findings, the researcher rejected the null hypothesis at 0.05 significant level since the beta value t-statistics was significant $(\alpha=0.000)$ concluding that government policy has a positive and significant effect on the relationship between strategic leadership and county government performance in the North Rift Region.

The current study was limited to government policy as a moderating variable but since a county government gets fund allocation according to its size and population, future studies could introduce other moderating variable for instance, county population and size to assess if there is any significant difference in strategic leadership practices on county performance.

The conceptual framework of this study can also be extended by considering more of the strategic leadership practices since the current study limited itself to only four and there could be other strategic leadership practices. For instance, future studies could consider adding more constructs of strategic leadership practices like determining strategic direction, emphasizing ethical practices, developing human capital and strategic control to see how these effect on the performance of county governments.

\section{References}

[1]. Afrobarometer (2014). Local Government in Kenya: Negative Citizen Perception And Minimal Engagement in Local Government Affairs. Briefing Paper No.89

[2]. Barling, J. (2014). Transformational leadership and El. Learnership \&Organisational Development Journal, 21(3):157-161.

[3]. Bonoff, N. \& Zimmerman, B. (2014). Research paper on the Budget management and accountability: Evidence from Kenyan Local Authorities.

[4]. Bourgeois, L. \& Bodwin, D. (2015). 'Putting your strategy into action', Strategic Management Planning, March/May.

[5]. Chandler, A. (2013). Strategy and Structure: Chapters in the History of the Industrial Enterprise, Cambridge, Mass: MIT Press.

[6]. Chandran, H. (2003) Educational Research: Contemporary Issues and Practical Approaches. London: Continuum.

[7]. Collins, J. (2014).'Level 5 Leadership: The triumph of humility and fierce resolve,' Havard Business Review Vol. 79, (1), 6676.

[8]. Copeland, D. (1943). Business strategy orientation, information systems orientation and strategic alignment. Information Systems Research, 8(2), 125-150

[9]. Cooper, D. \& Schindler, P. (2003). Business Research Methods.(8th edition). Boston: 15, McGraw-Hill Irwin.

[10]. Crossan, M. \&Bedrow, I. (2013). Organizational learning and Strategic Renewal".Strategic Management Journal, vol.24, pp.1087- 1105 .

[11]. David, F. (2013) Concepts of Strategic Management, 6th Ed. New Jersey, USA: Prentice Hall.

[12]. DiMaggio, P. \& Powell, W. (2014). "The Iron Cage Revisited: Institutional Isomorphism and Collective Rationality in Organizational Fields", American Sociological Review, vol.42, pp.113- 123 .

[13]. Finkelstein, S. and Hambrick, D. (2013). Strategic Leadership: Top executives and their effects on organizations. West Publishing.

[14]. Harrington, R. (2014). The moderating effects of size, manager tactics and involvement on strategy implementation in food service, Hospitality Management, vol 25 pp. 373-397. 
[15]. Higgins, M. (2005), The Eight 'S's of Successful Strategy Execution. Journal of Change Management. 5(1), 77-89.

[16]. Hoe S.L. (2008). Issues and procedures in adopting structura equation modeling technique, Journal of applied quantitative methods, Vol. 3(1)

[17]. Hubbard, G., Samuel, D. \& Heaps, S. (2014). The First X1: winning organizations in Australia, John Wiley, New York, NY

[18]. Johnson, D. (2015). Performance appraisal design, development and implementation, in the handbook of Human Resource Management, Ed. GR Ferrts, S.D. Rosen, and D.J Barnum, Blackwell, Cambridge, Mass.

[19]. Kane, J. (2014). The conceptualization \& representation of the total performance effectiveness, human recourse management Review, summer, pp 123- 45

[20]. Kaplan, R. \& Norton, D. (1996). Translating strategy into action: the balanced scorecard. Boston: Harvard Business School.

[21]. Kaplan, R. \& Norton, D. (2006). Alignment: using the balanced scorecard to create corporate synergies. Boston: Harvard Business School.

[22]. Kenya National Bureau of Statistics (2016).Economic Survey.Nairobi: Government Printer, p. 115

[23]. Kenya, IEBC (Independent Electoral and Boundaries Commission), 'Home', http://www.iebc. or.ke/index.php/Page-4.html, accessed 24 August 2015.

[24]. Kibua, T. \&Mwabu, G. (2016). Decentralization and Devolution in Kenya: New Approaches. Nairobi: University of Nairobi Press.

[25]. Koigi, A. (2014). Thesis on 'Improving Organizationa effectiveness of Public enterprises in Kenya'. Nelson Mandela Metropolitan University, Port Elizabeth.

[26]. Kombo, D.K \& Tromp, D. (2000). Proposal Writing and Theses Proposal: An Introduction Paulines Publications, Nairobi.

[27]. Krejcie, Robert V. Morgan, Daryle W. (1970). Determining Sample Size for Research Activities, Educational and Psychological Measurement.

[28]. Linchtensteui, M. \&Bannel.D. (2014). Spiritual perspectives on individual, Organizational and societal transformation.Journa of organizational change management, Vol. 12(3), 175-186.

[29]. Lynne, G. (2014). 'Postscript: microfoundations of institutional thought', in Walter W. Powell and Paul J. DiMaggio (eds), The New Institutionalism in Organizational Analysis, Chicago, IL: University of Chicago Press. Pp.103- 7.

[30]. Mboga, H. (2013). Local Government Systems in Kenya.Institute of Economic affairs, Nairobi.

[31]. Michelle K. \& Duffy, G. (2014)."Employee commitment and Organizational policies", Management Decision, Vol. 43 Iss: 2, pp. $203-219$.

[32]. Ministry of Planning State and National Development (MPN\&D), Kenya (2015).Public expenditure review (Policy for prosperity 2015).

[33]. Ministry of state for planning and National Development, Kenya (2014).Millennium Development Goals, Status report for Kenya.

[34]. Mitullah,W. (2014). Participatory Governance For Poverty Alleviation in Local Authorities In Kenya. Journal of Regional Development Dialogue Vol.25 No.1

[35]. Monica, D. \& Alex, Y. (2012). An empirical approach to the normality of experimental mathematics, Journal, Vol. 13lss: pp.37-41.

[36]. Mugenda, M. \&Mugenda, G. (2008). Research Methods: Quantitative Methods and Qualitative approaches. Nairobi, Acts Press.

[37]. Muia, D. (2015). Devolution of Governance to Districts in Kenya: A Case Study. In: Kibua, T.N AND Mwabu, G.eds.2015 Decentralization and Devolution in Kenya: New Approaches. Nairobi: University of Nairobi Press.
[38]. Mutuiri, J. (2015). Factors influencing Local Authority Transfer Fund Project Implementation: A case of Municipality of Meru County, Kenya, Unpublished MBA Project, University of Nairobi.

[39]. Mwabu, G. \&Kibua, T. (2016). Decentralization and Devolution in Kenya: New Approaches, Nairobi University of Nairobi Press.

[40]. Mwabu, G., Mwanzia, J. \&Liambila, W. (2014). User charges in government health facilities in Kenya: Effect on attendance and revenue, Health Policy and Planning, vol 10 pp.164-70.

[41]. Mwenda, A. (2015). 'Introduction in IEA Devolution in Kenya: Prospects, Challenges and the Future, IEA Research paper series No 24. Institute of Economic Affairs Nairobi.

[42]. Ndegwa, S. (2014).Decentralisation in Africa: a stock-taking survey. Africa Working Paper Series 40. Washington DC; WorldBank

[43]. Neely, A., Gregory, M. \&Platts, K. (2014).Performance Measurement System design and Literature review and research agenda. Int. Journal of production management Vol 15

[44]. O'Toole, J. \&Bennis, W. (2014). What's needed next? A culture of Candour. Havard Business review, June.

[45]. Ojo, O. (2013). Impact assessment of corporate culture on employee job performance. Business Intelligence journal, Vol.2, No. 2 pp. 388-97.

[46]. Oloo, A. (2016). Devolution and Democratic Governance: Options for Kenya. Nairobi, IPAR.

[47]. Paine, L. (2015). Cases in Leadership Ethics and Organizational integrity, Havard business Review 72 (2):106-17.

[48]. Pearce, A. \& Robinson, R. (2013). Formulation, Implementation, and Control of Competitive Strategy. McGraw Hill. New York.

[49]. Republic of Kenya (2012). The Transition to Devolved Government Act, Kenya: Government Printers.

[50]. Republic of Kenya (2013). The County Government Act, Nairobi, Kenya: Government Printers.

[51]. Ross, M. (2014). Thesis on 'Managerial leadership and Strategic performance in Public Organizations, A case of NewZealand Local Government Organizations.

[52]. Rummel, R. J (2002) Applied Factor analysis, Eraston K North WesternUniversity Press

[53]. Schein, E. (1992). Organizational culture and Leadership, 3rd (ed.). San Francisco: Wiley

[54]. Stogdill, R. \& Coons, A. (2015). Leader Behaviour: Its Description and Measurement, Research Monograph No.88, Ohio University.

[55]. Teece, D. (2012). Managing Intellectual Capital: Organizational, Strategic and Policy Dimensions, Oxford press. New York.

[56]. Thompson, A. (2012). Strategy: Core Concepts, Analytical tools, readings. McGraw- Hill. New York.

[57]. Transparency International- Kenya (2014).UfisadiJijini. Corruption in Services and Electoral Processes in Urban Kenya.

[58]. Turnbull, S. (2014). The planned and unintended emotions generated by a corporate change program. Advances in Developing Human Resources, vol.4 pp.22- 38.

[59]. Vandenberg, J., Richardson, A. \& Eastman, L. (2015). The impact of high involvement, work processes on organizational effectiveness; A second- order latent variable approach: Group and organizational management, Vol. 24 No. 3, pp.300-39.

[60]. Waldman, D., Bass, B. \&Yammarino, F. (2014).Adding to contingent-reward behavior, group Organizational studies, vol. 15,pp 382-94.

[61]. World Bank (2015).Economic Recovery Strategy for Wealth and Employment Creation 2014-2015. London Kogan: Government Printer. 